\title{
The Eocene-Oligocene ungulates from Western Europe and their environment
}

\author{
C. Blondel* \\ Laboratoire de Géobiologie, Biochronologie et Paléontologie Humaine, CNRS UMR 6064, Faculté des Sciences Fondamentales et Appliquées, \\ Université de Poitiers, 40, avenue du Recteur Pineau, F-86022 Poitiers Cedex, France
}

Received 16 March 1999; received in revised form 28 September 2000; accepted for publication 6 October 2000

\begin{abstract}
A survey of Paleogene ungulates from Western Europe is drawn up from the results of previous work on the ungulate lineages of this period and from new data on two groups particularly representative of the Oligocene ungulate fauna: the ruminants and the Cainotheriidae based on new material collected in localities of the Quercy Phosphorites. The history of ungulates from Western Europe at the Eocene-Oligocene transition is marked by different phases of extinction and origination related to environmental changes. In this perspective, the relative diversity of groups and the modifications of their tooth morphology, which reflect a diet change, resulting from vegetation modifications are analysed from the Early Eocene to the Late Oligocene. In Western Europe, the Late Eocene and the Early Oligocene was a period of transition with an important change in faunal and floral composition. The diversity analysis of ungulates suggests that the Grande Coupure is the result of gradual climatic and geographic events that occurred from the Middle Eocene (Mammalian Paleogene (MP)13/14 reference levels) to the Early Oligocene (MP 21/22 reference levels). During this period, it has been demonstrated that important adaptive changes occurred in the ungulate dental pattern (selenodonty in artiodactyls, semihypsodonty in perissodactyls), and appendicular skeleton (fusion of the cuboid and navicular bones of the tarsus in artiodactyls). These morphological modifications coincided with environmental changes that were less extreme than in North America. (C) 2001 Elsevier Science B.V. All rights reserved.
\end{abstract}

Keywords: Paleogene; Artiodactyl; Perissodactyl; Diversity; Diet

\section{Introduction}

A turnover in terrestrial and marine biota that reflects significant changes in ocean circulation and global climate (Cavelier, 1979; Berggren and Prothero, 1992; Pomerol and Premoli-Silva, 1986; Prothero, 1989; Prothero, 1994a,b) occurred around the Eocene-Oligocene transition.

In Western Europe, this period is characterized by an important turnover in mammalian faunas (Brunet,

\footnotetext{
* Tel.: +5-49-45-3925; fax: +5-49-45-4017.

E-mail address: cecile.blondel@univ-poitiers.fr (C. Blondel).
}

1977, 1979; Legendre and Hartenberger, 1992; Blondel, 1996). This event corresponds to the Grande Coupure as defined by Stehlin (1909). Numerous autochthonous lineages became extinct and Asian immigrants particularly the ruminants (Blondel, 1997), appeared in Western Europe at the EoceneOligocene boundary (Lopez and Thaler, 1974). This turnover is the result of important paleo-geographical changes: a land connection occurring between Europe and Asia caused by a marine regression (Haq et al., 1987) and by the Turgaï Straits closure (Pomerol, 1967), and the formation of a corridor in southeast Europe (Heissig, 1979; Ducrocq, 1995). 


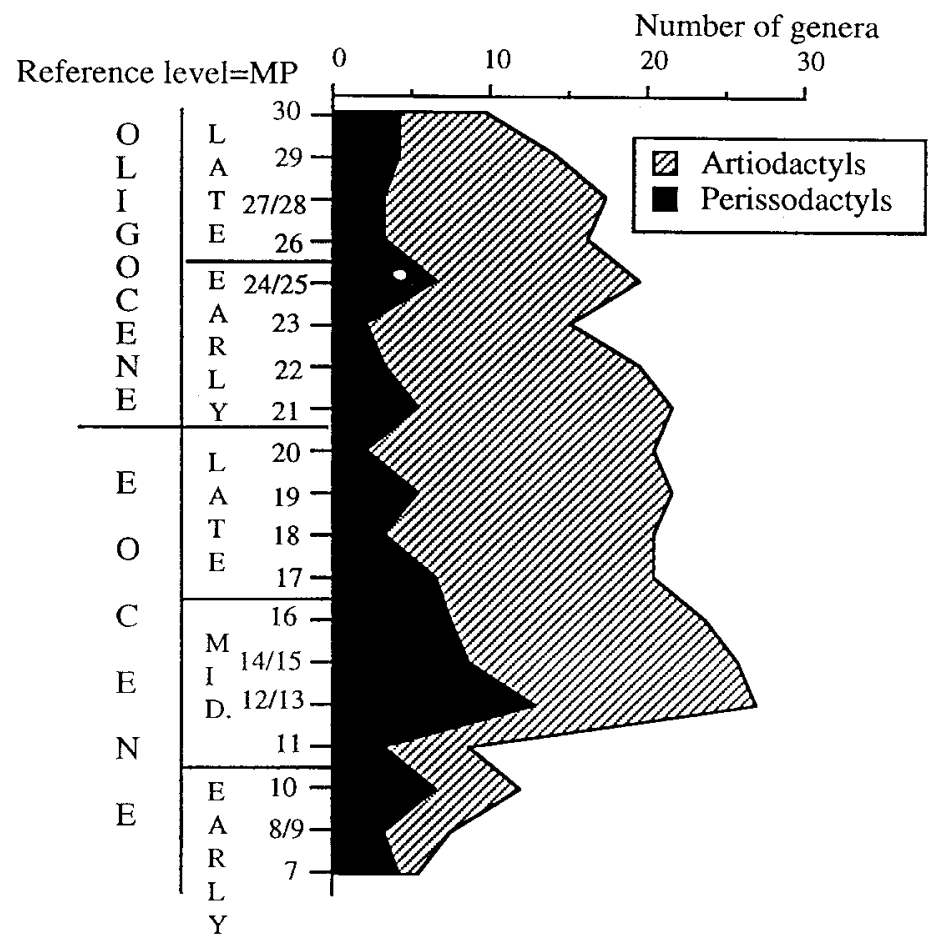

Fig. 1. Evolution of ungulate generic diversity in Europe during the Eocene and the Oligocene.

The Paleogene mammalian faunas have been analysed over the last ten years on the basis of abundant dated material collected in Germany, England and in the Quercy Phosphorites karstic localities of southwestern France that were exploited for twenty five years. Then, the study of some Paleogene lineages led to elaboration of a reference level scale (Mammalian Paleogene (MP), see Fig. 1) defined at the Mainz Symposium in 1987 (SchmidtKittler, 1987; Aguilar et al., 1997). Study of mammalian faunal evolution during the Paleogene has pointed out the diversification phases in different mammalian groups such as ungulates or rodents (Vianey-Liaud and Legendre, 1986; Vianey-Liaud, 1991; Sudre and Legendre, 1992). From community analyses, correlations have also been established between these phases of originations and extinctions with the important environmental changes that occurred from the Middle Eocene to the Early Oligocene (Legendre, 1986, 1987; Legendre et al., 1991; Sudre and Legendre, 1992).

The purpose of this paper is to study precisely the relationships between the evolution of ungulates and climatic and vegetational changes during the Paleogene in Western Europe. Therefore, on the basis of new systematic data on the Oligocene ruminants (Sudre and Blondel, 1996; Blondel, 1997) and the European autochthonous forms, the post Grande Coupure Cainotheriidae (Blondel, 1996), the previous analyses are extended to the determination of the ungulate diet which is based on dental characters such as cusp shape and hypsodonty and on types of digestive physiologies. From all the characters, five categories have been established, roughly linked with ungulate diet and environment.

In this study, evolution of the specific diversity, and changes in the diet of the artiodactyls and perissodactyls between the Early Eocene and the Late Oligocene are analysed. These results will be compared with previous works on European (Legendre, 1987; Legendre et al., 1991; Sudre and Legendre, 1992; Leduc, 1996) and North American faunas of the same age (Cifelli, 1981; Janis, 1989, 1993, 1998; Prothero and Heaton, 1996; Stucky, 1995). These results give new information on ungulate evolutionary history from the Paleogene of Western Europe. They 
also bring a new point of view on the Eocene-Oligocene extinction crisis.

\section{Materials and methods}

\subsection{Diversity analyses}

The diversity of artiodactyls and perissodactyls is analysed from the Early Eocene to the Late Oligocene. In order to make an inventory of the Paleogene ungulate lineages, different works and syntheses on some systematic groups were taken into consideration: the Eocene Equoidea (Hooker, 1989, 1994; Franzen, 1995); the Eocene Ceratomorpha (Fischer, 1964; Dedieu, 1976); the Eocene artiodactyls (Sudre et al, 1983; Sudre and Marandat, 1993; Sudre and Erfurt, 1996; Erfurt and Haubold, 1989; Erfurt, 1995; Erfurt and Sudre, 1995a,b, 1996; Smith et al. 1996); the Oligocene ungulates, namely the Entelodontidae (Brunet, 1979); the Suidae (Hellmund, 1992); the Anthracotheriidae Elomeryx (Hellmund, 1991); the Palaeotheriidae (Brunet and Jéhenne, 1989; Rémy, 1995); the ruminants (Bouvrain et al., 1986; Sudre, 1986; Sudre and Blondel, 1996; Blondel, 1997); the Cainotheriidae (Sudre, 1995); and the updated faunal lists or the monographs of Paleogene localities (Rémy et al., 1987; Legendre, 1989; Jéhenne and Brunet, 1992; de Bonis, 1995a).

The specific diversity is established from faunas belonging to a restricted bio-geographical area (southern France) in order to avoid the provincial effects observed in some groups, and the correlation problems between the Western European province localities (Legendre et al., 1991). The scarcity of ungulates in some reference level localities (MP 12, MP 15, MP 27) or the absence of ungulate bearinglocalities in the MP 24 reference level required combining each of these reference levels with the succeeding one, except for the MP 15 reference level, which cannot be associated.

\subsection{Dental pattern analyses}

The numerous originations and extinctions within ungulates reflect the important adaptive changes that can occur in their physiology, their dental function, and their locomotion. The type of digestive physiology is a critical aspect of the biology of an herbivorous mammal (Janis, 1989). For the fossils, the evolution of dental morphology is related to the dietary modifications that are in turn connected to physiological changes in the process of digestion. Different analyses based on comparisons with extinct forms were proposed to interpret these fossils in this way (Janis, 1989, 1995; Langer, 1987; Vianey-Liaud, 1991). Thus, five feeding categories have been distinguished roughly. They are based on the cusp shape, the hypsodonty and the main types of digestive physiologies established from extant species with known diet. The changes in tooth crown height and cusp shape of the cheek teeth are related to the relative amount of fibre in the diet in a wide variety of herbivores. A generalized frugivore/omnivore has brachydont cheek teeth with rounded cusps, the red colobus monkey which eats more fruits has more developed crests. A frugivore/folivore as the lesser mouse deer (bunoselenodont artiodactyl) or the tree hyrax (bunolophodont perissodactyl) has brachydont cheek teeth with crests and lophs. The increase of fibre in the diet coincides with the development of crests and lophs and the hypsodonty. A folivore as the impala has mesodont selenodont cheek teeth. Grazers such as the wildebeest and the common zebra have hypsodont selenodont cheek teeth and hypsodont plagiolophodont cheek teeth, respectively (Janis, 1989, 1995, fig. 5.2). These observations on teeth of living species with known diet allow different groups of Paleogene ungulates to be classified. For this analysis, the geographic area is Western Europe.

Category 1. Artiodactyls with brachyodont and bunodont cheek teeth might have had a frugivorous-omnivorous diet with little or no fermentation of cellulose in a forestomach (Janis, 1976). This category includes the Diacodexiedae, the Dichobunidae, the Cebochoeridae, the Choeropotamidae, the Suidae, the Tayassuidae, the Entelodontidae, and also some primitive Haplobunodontidae.

Category 2. Artiodactyls with a lophed structure on their brachyodont molars that prefigure the selenodonty. The bunoselenodont forms that appeared at the MP 11/12 reference levels were adapted to a mixed frugivorous/folivorous diet (Janis, 1995). The selenodont forms that are known from the MP 14 reference level had a folivorous diet. This category includes some primitive families that appeared in the Middle Eocene: the Dacrytheriidae, the 


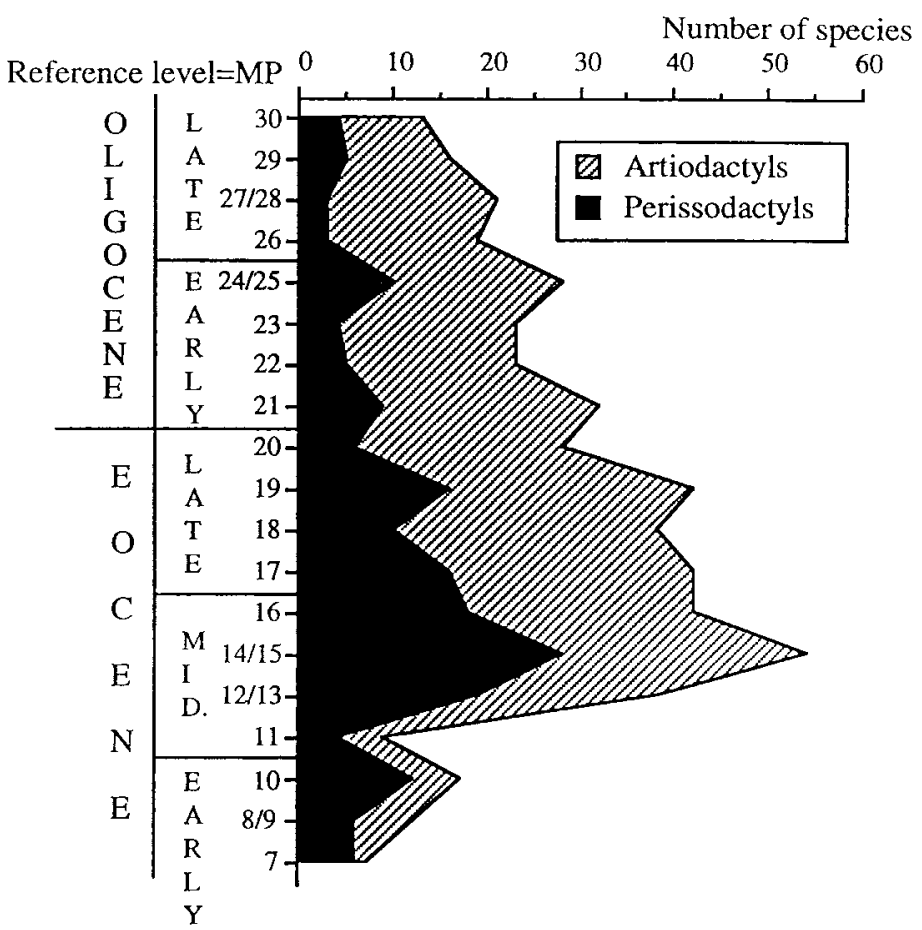

Fig. 2. Evolution of ungulate specific diversity during the Eocene and the Oligocene.

Mixtotheriidae, the Anoplotheriidae, and the Oligocene Anthracotheriidae. Other forms with more selenodont cheek teeth such as the Cainotheriidae, the Amphimerycidae and the Xiphodontidae also belong to this category. According to Janis (1989), the Cainotheriidae, together with the Amphimerycidae, would have had a digestive physiology close to that of the extant Tragulidae. However, they preserve a primitive tooth pattern in their upper molars with five cusps. Their physiology differed from that of the extant Tragulidae because of their very small size (see discussion). They are closer to the forms included in the second category, and thus they differ from those included in the third category. The Xiphodontidae that have five cusps are included into the second category. The xiphodontid genus Dichodon has four cusped selenodont molars like those of ruminants that are included in the third category. However, the genus Dichodon has small lateral folds on upper molars, a strong posterior cingulum and a postentocristid distal extension on lower molars as in the Amphimerycidae or Robiacina. According to these features, the Xiphodontidae (s. 1.) are included in the second category.
Category 3. Artiodactyls with selenodont cheek teeth such as the extant Tragulidae. These smallsized ruminants have a poorly developed fermentation, but they have the capacity to handle a greater degree of fibre in the diet than non-ruminant herbivores (Category 1 and 2). The Tragulina include a few genera (Lophiomeryx and Bachitherium) with tetraselenodont upper molars. They are characterized by several primitive features such as the lack of entocristid on lower premolars, non-alignment of the astragalus trochlea (Brunet and Sudre, 1987; Martinez and Sudre, 1995). However, the species Lophiomeryx chalaniati, Bachitherium curtum, B. lavocati and B. cf. insigne, which had an estimated body weight higher than $5 \mathrm{~kg}$ (Blondel, 1998), might have developed rumination. Most of them might have been adapted to a folivorous diet (see discussion further).

Category 4. Pecora including forms with brachyodont and tetraselenodont cheek teeth, which significantly modified some parts of their dentition (loss of upper incisors, incisor-like canines, large diastema between $\mathrm{C}$ and $\mathrm{P} / 2$, presence of lower premolar entocristid). Most of them were adapted to a folivorous 


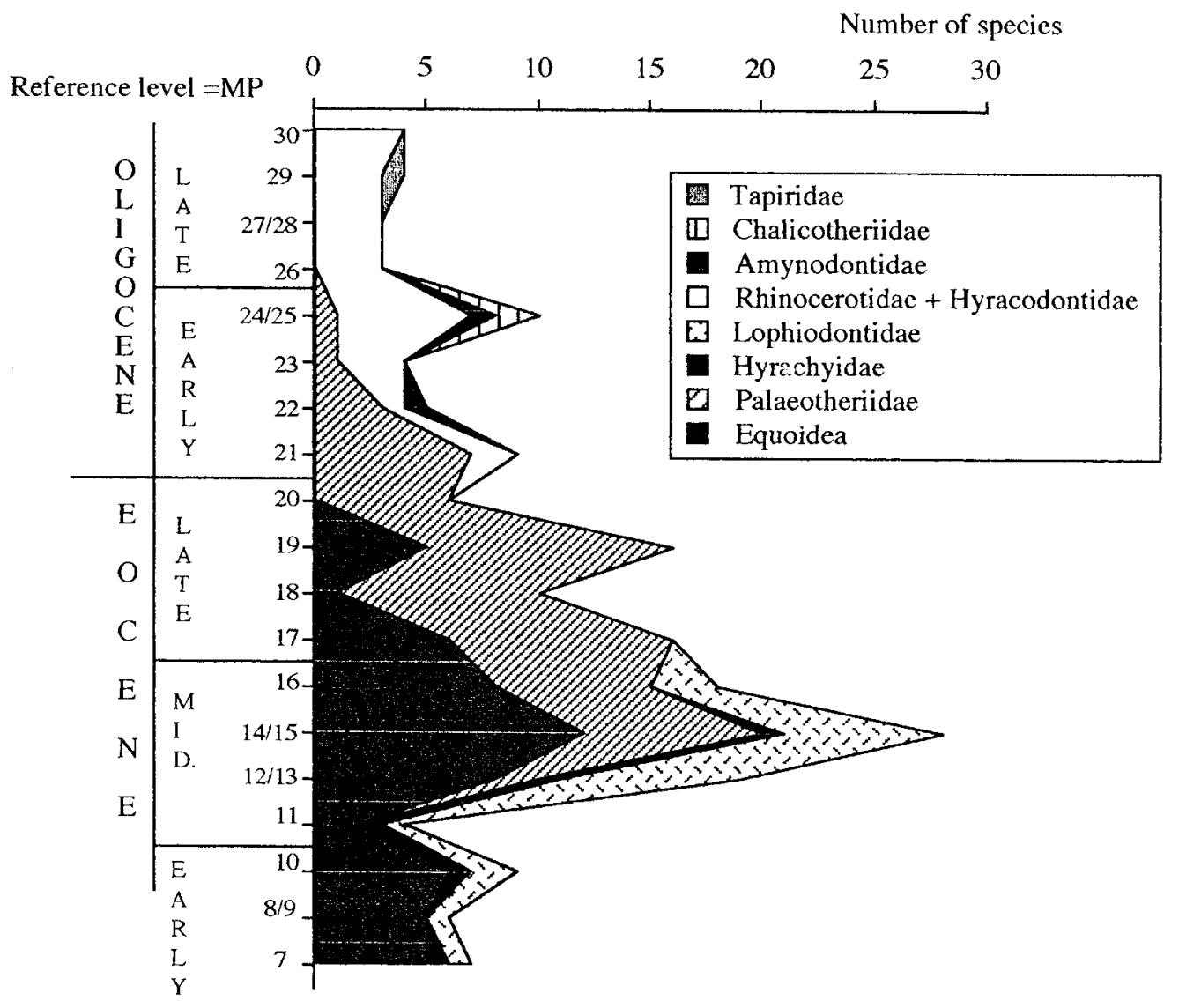

Fig. 3. Evolution of specific diversity in perissodactyls during the Eocene and the Oligocene.

diet (Janis, 1995). The forestomach fermentation might have been strongly developed and the cud was chewed.

Category 5. The last category includes Perissodactyla, which are hindgut fermenters. The Early Eocene forms such as Equoidea (Prothero and Schoch, 1989) are characterised by their prelophodont molars. This group was categorized as mixed frugivore/herbivore browser (Collinson and Hooker, 1987). The large-sized perissodactyls, such as the Lophiodontidae and the Hyrachyidae, with bilophodont teeth were adapted to a folivorous diet. The selenolophodonty developed in some groups in the Middle Eocene was also adapted to a frugivorous/ folivorous diet, as indicated by the well conserved stomach contents of Propalaeotherium from Messel (Sturm, 1978). At the end of the Middle Eocene, molarization of the premolars and the development of semihypsodonty indicate a diet composed of more fibrous plants, although the microwear study in the semihypsodont palaeothere Plagiolophus suggests that this genus was a browser (Collinson and Hooker, 1991). These characteristics are much more marked in the Oligocene Rhinocerotidae and the Amynodontidae (see discussion).

\section{Results}

The generic and specific diversity analyses (Figs. 1 and 2) suggest that the two orders evolved at the same time in Europe, as Cifelli (1981) showed for the North American ungulates. Although the number of perissodactyls strongly decreased and that of bunoselenodont and selenodont artiodactyls increased at the same time (Fig. 5), artiodactyls and perissodactyls evolved 


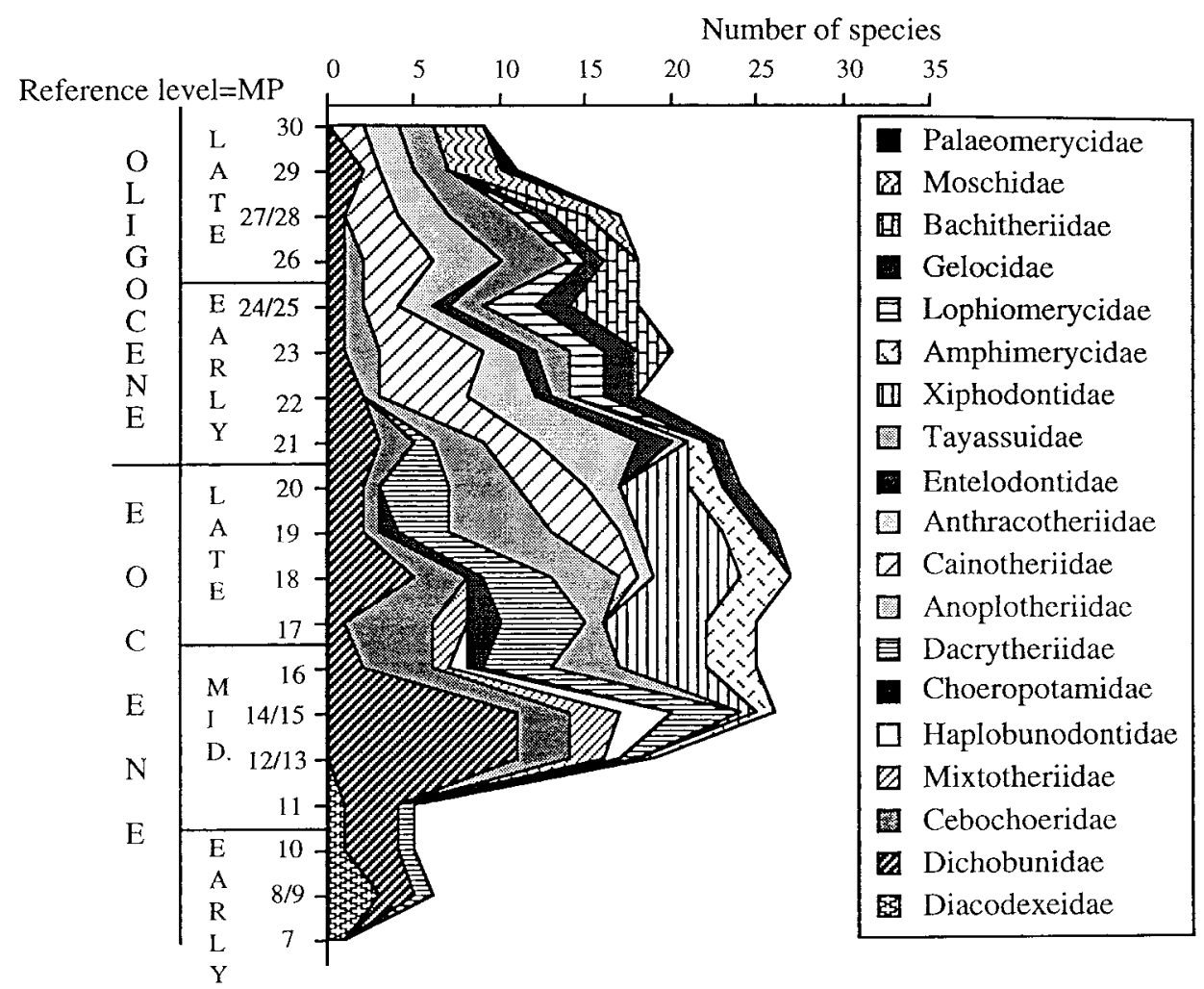

Fig. 4. Evolution of specific diversity in artiodactyls during the Eocene and the Oligocene.

independently despite the ecological similarity and their convergence of dental pattern. They had different digestive physiology (Janis, 1989) and probably they did not share exactly the same adaptive zone (Sudre and Legendre, 1992). Moreover, the generic diversity of artiodactyls is much higher than that of perissodactyls (Fig. 1). This might be due to the heterogeneity of artiodactyl dental characters with respect to the homogeneity of perissodactyl dental pattern.

The main episodes of the evolutionary history of these two groups seem to coincide. From the Middle Eocene to the Late Oligocene, the general decrease in ungulate specific diversity (Fig. 2) can be correlated with the major global cooling (Zachos et al., 1993, 1994). The evolution of the artiodactyl and perissodactyl specific diversity shows that the importance of both groups depends on factors such as geography and climate (Legendre, 1987; Legendre and Hartenberger, 1992; Janis, 1989, 1993; Sudre and Legendre, 1992).

From the known fossil record, perissodactyls and artiodactyls appeared at the beginning of the Early Eocene (MP 7 reference level), the former with the equoids and tapiromorphs (Hooker, 1994), the latter with the Diacodexeidae (Figs. 3 and 4). The same situation is observed in North America that was connected to Western Europe by Greenland and Scotland at that time. The geographical origin of these two groups is unknown, although several different hypotheses have been advanced (e.g. Estravis and Russell, 1989; Gingerich, 1989; Smith et al., 1996; Beard, 1998). The paleobotanical data (Chateauneuf, 1986; Ollivier-Pierre et al., 1987) and the marine $\delta^{18} \mathrm{O}$ isotopic curve (Zachos et al., 1993) indicate a warm climate and a drier environment during the Early Eocene, which coincide with the diversification of artiodactyls and perissodactyls.

During the Early Eocene, the opening of the North Atlantic Ocean stopped the communication between North America and Europe (MacKenna, 1980, 1983a, b). Thus, the European fauna became strongly endemic (Hartenberger, 1983, 1987). Among 


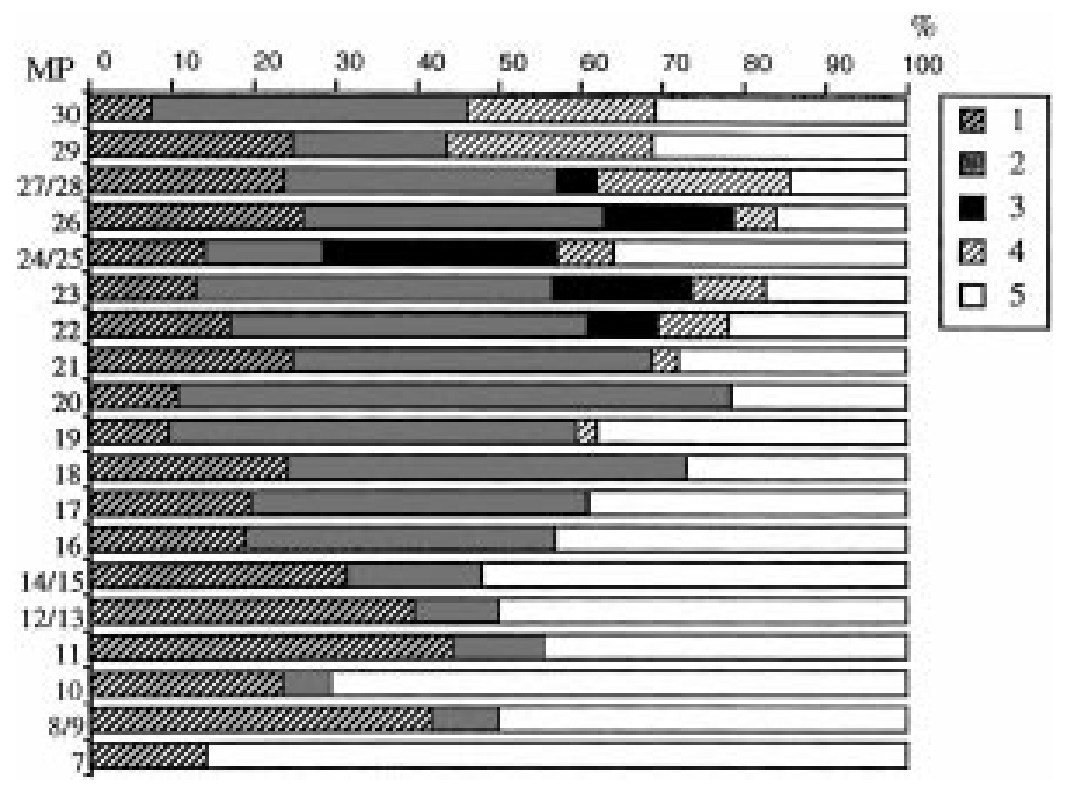

Fig. 5. Evolution of percentages of ungulate species of different dietary types during the Eocene and the Oligocene: (1) Artiodactyls with brachydont bunodont cheek teeth and with little or no fermentation; (2) Artiodactyls with brachydont lophed molars, with bunoselenodont and selenodont cheek teeth, and with forestomach fermentation; (3) Ruminants with little developed fermentation; (4) Ruminants with developed forestomach fermentation plus cud-chewing; (5) Perissodactyls with hindgut fermentation.

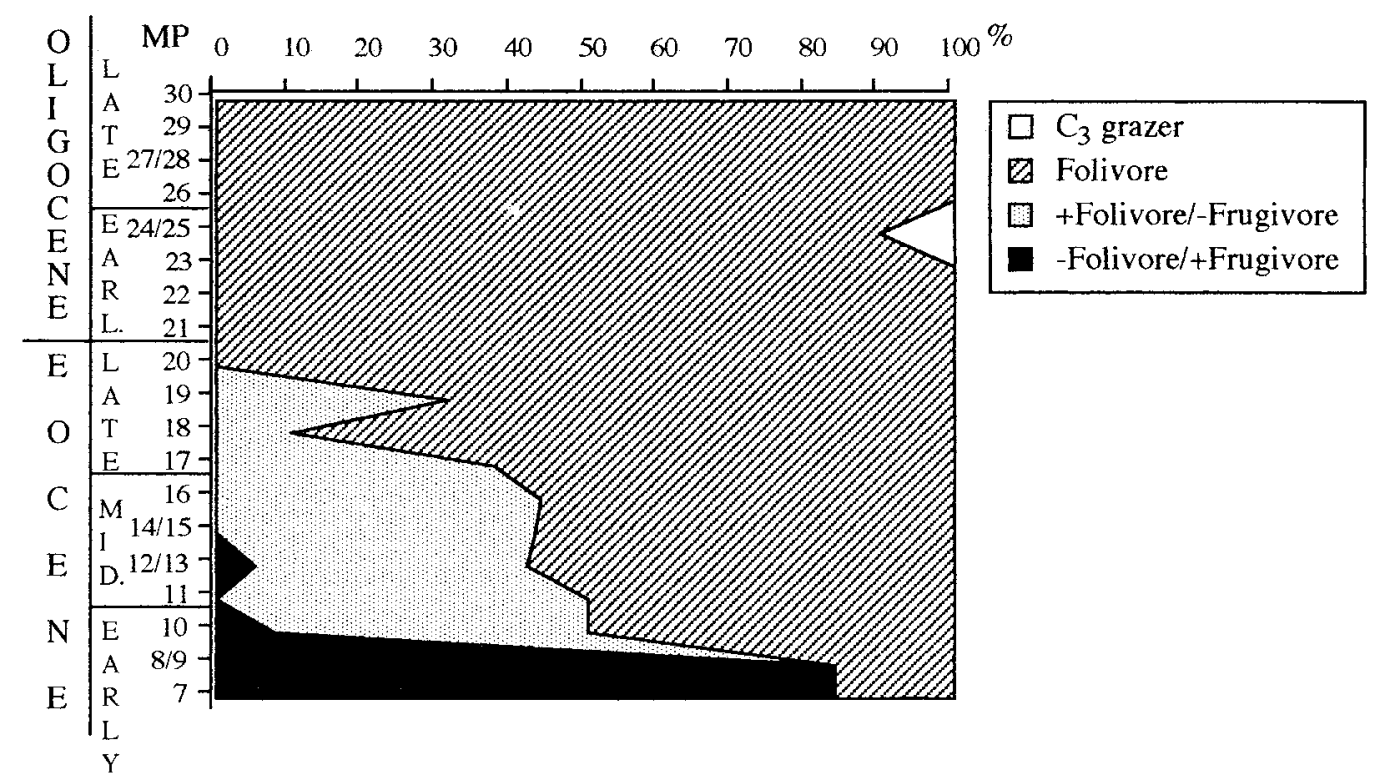

Fig. 6. Evolution of diet in perissodactyls in Europe during the Eocene and the Oligocene. 
perissodactyls, the Equidae, the Lophiodontidae and the Hyrachyidae became diversified at the end of the Early Eocene (MP 10 reference level). They included at least $70 \%$ of the total ungulate species fauna and $80 \%$ were frugivorous (Figs. 5 and 6). This diversification also occurred among the artiodactyls deriving from Diacodexis that was the ancestor of different lineages during this period (Sudre et al., 1983).

During the Middle Eocene, the evolution of Equoidea showed that an important episode in the history of this group occurred at the MP 13 reference level with the origination of the Palaeotheriidae (Plagiolophus and Palaeotherium) characterized by teeth that were much more hypsodont than those of contemporaneous Equidae (Franzen, 1995). The maximum diversity in Lophiodontidae lineages is observed at this reference level (Fig. 3).

During this period, an important diversification of artiodactyls also occurred with the appearance of the Dichobunidae, Dacrytheriidae, Cebochoeridae, and Haplobunodontidae. The perissodactyl species number was higher than that of the frugivorous/folivorous artiodactyls, and their diversity increased with respect to that of the omnivorous/frugivorous artiodactyls (Fig. 7). These episodes seem to be correlated with a tropical climate. Floral evidence shows that the forests at the beginning of Middle Eocene were tropical and paratropical (Collinson and Hooker, 1987; Collinson, 1992). The Palaeotheriidae, the Dacrytheriidae and the Mixtotheriidae diversified at the MP 14 reference level together with the first selenodont artiodactyls, the Xiphodontidae (Haplomeryx and Dichodon) and the Amphimerycidae (Pseudamphimeryx), which appeared at that time. During this period (the end of the Lutetian), artiodactyl diversity is the highest while several Palaeotheriidae lineages originated among the perissodactyls. These episodes of diversification coincide with a floristic change that indicates a cooling and a drying around the MP 13/14 reference levels (Collinson et al., 1981; Janis, 1993).

At the Middle Eocene/Late Eocene boundary, the Equidae decreased, whereas the Lophiodontidae became extinct at the MP 16 reference level. The Palaeotheriidae Leptolophus, which is characterized by a marked hypsodonty and the artiodactyls Robiacina and Robiatherium, appeared at this reference level. The two latter genera prefigured more recent groups such as the Cainotheriidae and the Anoplotheriidae (Diplobune and Anoplotherium) known at the MP18 reference level. During this period (Middle Eocene/Late Eocene), the vegetation was less tropical

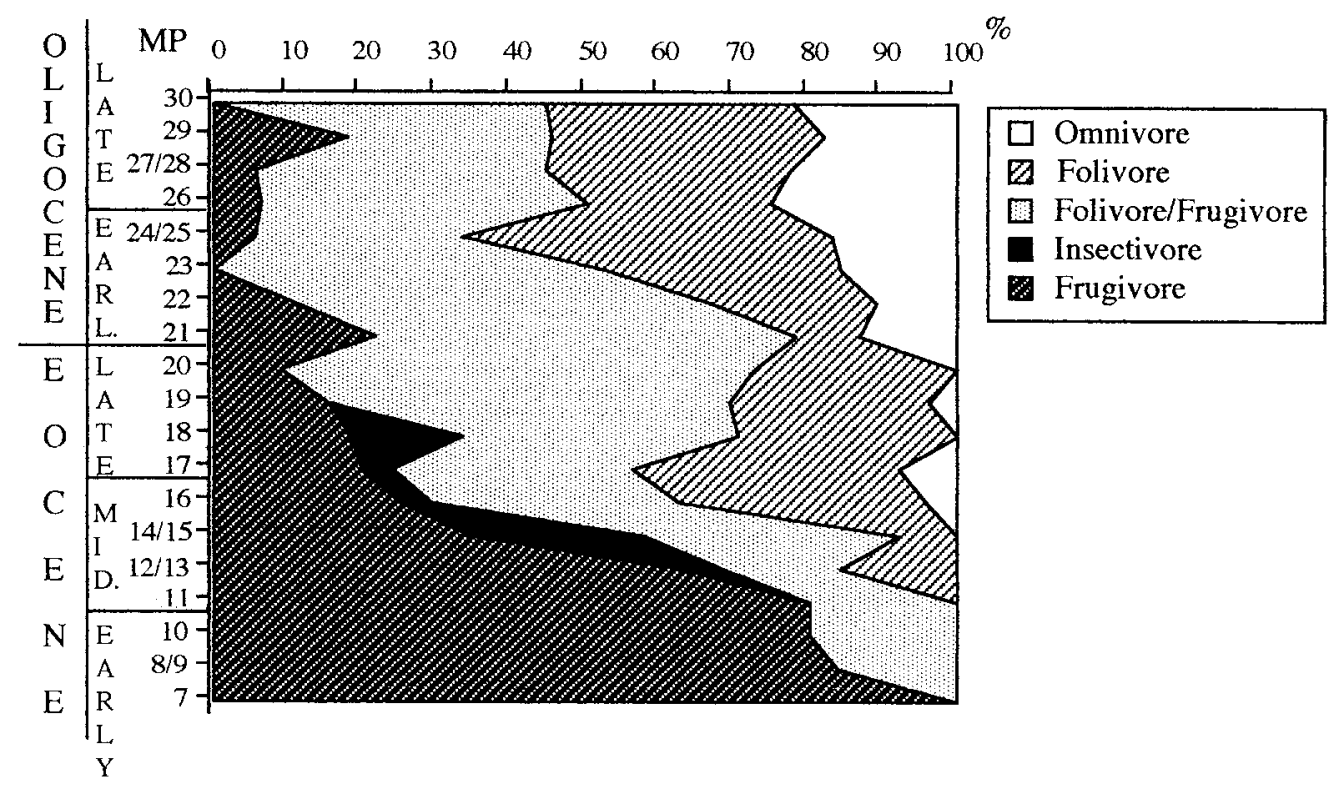

Fig. 7. Evolution of diet in artiodactyls in Europe during the Eocene and the Oligocene. 
than earlier. The subtropical evergreens were dominant (Collinson and Hooker, 1987; Collinson, 1992).

At the beginning of Late Eocene (MP 16/17 reference levels), the percentage of perissodactyls ( $70 \%$ of folivorous forms) decreased, whereas that of frugivorous/folivorous (bunoselenodont) and folivorous (selenodont) artiodactyls increased with the appearance of Anoplotherium and the Cainotheriidae (MP 18 reference level) and of the first Asian immigrants: the Anthracotheriidae (Elomeryx crispus) at the MP 18 reference level (Hellmund, 1991) and the Gelocidae Phaneromeryx (P. gelyensis from St Gély, MP 19). This immigration was a consequence of modification of the European paleogeography. At the EoceneOligocene boundary, Europe was in connection with Asia because of the drying of the Turgai Straits (Pomerol, 1967), and because a drop in sea level occurred worldwide (Haq et al., 1987). Corridors of migration might have been open between Asia and southeastern Europe (Balkan archipelago, Iran, Anatolia) during the Late Eocene (Heissig, 1979; Ducrocq, 1995).

No correlation can be drawn between the decrease in diversity of perissodactyls and the increase in immigrant ruminants, very few of which appeared before the Grande Coupure (Phaneromeryx) and the increase in selenodont autochthonous artiodactyls (Xiphodontidae, Amphimerycidae). This great change in diversity can be correlated with the important climatic change which occurred at the Late EoceneEarly Oligocene. The European flora suggests a drier climate with marked seasonality, and the tropical and subtropical forests was replaced by temperate, mixed deciduous floras that led the habitats to become more open (Collinson and Hooker, 1987; Ollivier-Pierre et al., 1987; Gruas-Cavagnatto, 1974). This flora did not show variations of cooling and drying as extreme as those that occurred in North America (Wolfe, 1978, 1985; Prothero, 1994b; Wing, 1998), because Europe was an archipelago in the tropical Tethys Sea (Pomerol, 1967; Berggren and Prothero, 1992).

The Eocene-Oligocene transition (MP 20/21 reference levels) was marked by the extinction of several artiodactyl families: the Hyperdichobuninae, Choeropotamidae, Xiphodontidae. Some autochthonous artiodactyls persisted at the Grande Coupure: the Dichobunidae (Dichobune and Metriotherium), Cebochoeridae (Cebochoerus), Dacrytheriidae (Tapirulus),
Anoplotheriidae (Diplobune), and the Amphimerycidae (Amphimeryx) (Legendre et al., 1995). Only the lineages of Dichobune, Metriotherium and Diplobune persisted during the Late Oligocene. Although small ruminants appeared (see above) and small artiodactyls (Amphimerycidae) were already present, the Cainotheriidae rapidly diversified in the Early Oligocene (Blondel, 1996). Their ecology must have been specialized: their brachyo-selenodont molars suggest a frugivorous/folivorous diet, but they might have been more generalist feeders. The Entelodontidae, the anthracotheriid Anthracotherium, the gelocid Gelocus, the suid Palaeochoerus, the Rhinocerotidae, the Hyracodontidae, and also the Tapiridae appeared at the MP 21 reference level. The MP 22 reference level was marked by an important diversification of ruminants with the appearance of the Lophiomerycidae, the Bachitheriidae and the Gelocidae such as the small Pseudogelocus scotti. The discovery of this species in a Quercy locality (Mas de Got, MP 22 reference level) challenged the hypothesis (Jéhenne, 1985) that these small-sized forms were only represented in southern Germany (Sudre and Blondel, 1996). The ruminants are characterised by tetraselenodont upper molars, the loss of all upper incisors and the fusion of the cuboid and navicular bones in the tarsus. The latter feature that unites the Ruminantia was present in the autochthonous Amphimerycidae. This family had derived features such as very elongated premolars, and primitive features such as selenodont triangular upper molars with five cusps. The Amphimerycidae were very small sized artiodactyls (about $0.4-1.5 \mathrm{~kg}$, according to Martinez and Sudre, 1995), and they probably were not ruminants (Janis, 1976). They became extinct in the Early Oligocene (Legendre et al., 1995), probably due to competition with other small ruminants. The last species Amphimeryx riparius might have subsisted in the Ronzon locality (MP 21 reference level) (Stehlin, 1909).

The important global cooling due to the ocean circulation change, particularly the development of cold bottom waters from poles (Miller, 1992) which occurred in the Early Oligocene, may be correlated with a decrease in ungulate diversity. However, the latter was not marked because it was compensated for by the arrival of several Asian immigrants. The appearance and the morphological features of some perissodactyls and artiodactyls suggest an opening of 
their habitat that seems to have been more marked at the beginning of the Late Oligocene. The amynodontidae, more hypsodont perissodactyls, appeared at the MP 22 reference level, and the Chalicotheriidae at the MP 23 reference level (de Bonis, 1995b,c). In the Amynodontidae (Cadurcotherium, MP 25 reference level), the presence of cement and higher tooth crowns suggests a diet composed of very abrasive elements such as grit, silica phytoliths. The palaeotheriid Plagiolophus became extinct at the MP 25 reference level, and only the rhinocerotidae diversified in the Late Oligocene (de Bonis and Brunet, 1995). The entelodontids became extinct probably at the MP 24 reference level and the anoplotheriids disappeared at the MP 27 reference level. Stability seems to have been observed in the evolution of the Suidae between the Early Oligocene and the Late Oligocene (Hellmund, 1992). Primitive ruminants such as the Lophiomerycidae, Bachitheriidae, which represented $30 \%$ of the ungulate species at the MP 24/25 reference levels, and the gelocidae became extinct at the beginning of the Late Oligocene (MP 28 reference level). They were replaced by other Asian immigrants, the moschid Dremotherium quercyi and the Palaeomerycidae (MP 27/28 reference levels).

\section{Discussion and conclusions}

From these data and previous studies (Sigé and Vianey-Liaud, 1979; Legendre, 1987; Legendre and Hartenberger, 1992), the Late Eocene to Early Oligocene was a period of transition with important changes in faunal and floral composition. The results lead us to infer that the Grande Coupure was not an extinction crisis, but corresponded to a complex event, which can be separated into different waves of extinction and origination, resulting from progressive climatic and geographic events that occurred from the Middle Eocene (the end of the Lutetian, MP 13/14 reference levels) to the Early Oligocene (MP 21/22 reference levels). These results improve upon those of previous studies on ungulates of Western Europe (Sudre and Legendre, 1992), mainly because of the more abundant fossil record and because of new data on the autochthonous groups such as the Late EoceneOligocene Cainotheriidae and on the Asian immigrant ruminants. These analyses of ungulate diversity tend to confirm the results of Leduc (1996), who does not observe major diversity decrease of the whole European mammalian fauna during the EoceneOligocene transition, as it was compensated for by the immigration of Asian groups from the Late Eocene onwards. After having studied the Late Eocene-Early Oligocene mammalian fauna in North America, in particular the specific diversity of mammals from the White River Group in the High Plains, Prothero and Heaton (1996) suggested that the majority of mammalian lineages persisted during this period. They showed that there were no real adaptive changes in many mammalian species in response to the vegetation that changed from dense forests to open forested grassland (Retallack, 1992). However, in Western Europe, it has been demonstrated that important adaptive changes occurred in the dental pattern and the appendicular skeleton of ungulates and that they coincided with climatic and geographic events less extreme than in North America. During the Middle Eocene, the appearance of premolar molarization and the development of semihypsodonty (Leptolophus) in perissodactyls and of selenodonty in artiodactyls (Amphimerycidae, Xiphodontidae) indicate a diet composed of more fibrous elements, correlated with the less tropical climate. At the beginning of the Late Eocene, some groups such as the Amphimerycidae, which fused the cuboid and navicular bones of the tarsus, were adapted to a more open habitat and the appearance of seasonality. Moreover, many frugivous/folivorous archaic families (Haplobunodontidae, Hyperdichobuninae, Mixtotheriidae) and folivorous groups (Dacrytheriidae, Xiphodontidae, Choeropotamidae) became extinct before and after the Grande Coupure (MP 20/MP 21 reference levels). Other families such as the more generalist Cainotheriidae or the omnivorous/insectivorous Dichobunidae survived at the beginning of the Early Oligocene. From paleo-botanical data (Leopold et al., 1992; Wing, 1998), this period corresponds to a global drastic cooling and a drying. The study of paleosols of North America (Retallack, 1992) indicate the development of woody savannas in some areas of that continent. In Western Europe, we observe the presence of conifers, temperate woodlands and in some areas of France, the occurrence of savanna Umbelliferae (Ollivier-Pierre et al., 1987). The 
appearance of more hypsodont rodents (Issiodoromys, Vianey-Liaud, 1991) and the mammalian community analyses (Legendre, 1986, 1987) also suggest a drier habitat in France during the Early Oligocene. In response to these environmental modifications, some perissodactyls developed hypsodonty (Cadurcotherium), but the ruminants retained their brachyodont condition during the Oligocene. Among the artiodactyls, some species such as Lophiomeryx chalaniati, Gelocus communis, Bachitherium curtum, Bachitherium cf. insigne and Dremotherium quercyi may have been folivorous. The appendicular skeleton of $G$. communis and B. curtum indicate that they may have lived in wooded to semi-aquatic habitats. $L$. chalaniati may have lived on swamp sides, and $B$. insigne and D. quercyi may have lived in light forests (Blondel, 1998). In contrast, evidence that, Prodremotherium elongatum and Bachitherium lavocati may have lived in a more open habitat than the previous species, and the preliminary study on the tooth microwear of Lophiomeryx mouchelini (Blondel, 1996) both suggest that these species may have been grazers or mixed feeders, rather than browsers, or alternatively that grit may have been included in their diets. Modern grasslands are characterised by Gramineae, forbs and few low shrubs and woody plants (Macfadden, 1997). Most present-day grasses and grassland biomes in tropical and temperate climates involve $\mathrm{C} 4$ plants. The trees, shrubs, and high altitude and high latitude grasses are C3 plants (Tieszen et al., 1979). The presence of grasslands is not very clear before the Late Miocene. From the isotopic signal in carbon (Cerling, 1992; Cerling et al., 1997, 1998; Ehleringer et al., 1991; Wang et al., 1994), C4 plants appeared in North and South America, Africa and Asia about 7-8 Ma ago, and their appearance was favoured by a significant decrease in levels of atmospheric $\mathrm{CO}_{2}$, increasing aridity and more pronounced seasonality. However, recent molecular isotopic analyses suggest that $\mathrm{C} 4$ grasses occurred before the Miocene (Kuypers et al., 1999; Pagani et al., 1999). Moreover, the study of paleosols (Retallack, 1992) and the presence of fossil grasses recorded in the Brule Formation (North America) (Macginitie, 1953; Galbreath, 1974) indicate that grasslands appeared during the Oligocene, and developed from the Early Miocene onwards (Stebbins, 1981). In France, woody savannah is present from the Early Miocene (Wolfe, 1985; Roiron, 1992), but some open areas with $\mathrm{C} 3$ plants have been reported during the Oligocene (Ollivier-Pierre et al., 1987; Blondel et al., 1997). It is thus possible to infer that a mosaic of landscapes with temperate and coniferous forest, woodland, more open areas occurred in Western Europe, during the Oligocene. Some frugivorous and folivorous ungulates lived in these forests and woodland, and others such as Cadurcotherium, Bachitherium lavocati, Prodremotherium elongatum and Lophiomeryx mouchelini most likely lived in more open habitats, feeding on shrubs and C3 herbs. The dental abrasion in ungulates can result from the accumulation of grit on the food and the presence of opaline phytoliths contained in plants (monocots, and also dicots) (Baker et al., 1959; Janis, 1988; Piperno, 1989) and from the quantity of siliceous particles in these plants. This quantity is more important in grasses (Stebbins, 1981; Macnaughton et al., 1985). These authors suggested that a co-evolution exists between the herbivores and grasses, resulting in higher concentrations of silica (as a plant defence mechanism) in heavily grazed areas. It can be assumed that during the Oligocene the degree of hypsodonty in some hindgut fermenters (Rhinocerotidae) was higher than in ruminants because they ingested much more $\mathrm{C} 3$ herbs than the latter, and because of the difference in digestive physiology between perissodactyls and artiodactyls. A ruminant that has a foregut fermentation site ingests less food daily than a perissodactyl of similar body size, which is a hindgut fermenter (Janis, 1976, 1989). Equids, which have both a highly abrasive diet, and a large daily intake show a hypsodonty significantly greater than the other ungulates (Janis, 1988). During the Oligocene, plants were probably less abrasive than during the Miocene. Tooth wear was therefore less important for the ungulates, particularly for the ruminants. Therefore, the ruminants conserved their brachyodonty and some perissodactyls had semihypsodont cheek teeth during this period. Most of these primitive families became extinct during the Miocene, and they were replaced by hypsodont forms because of the development of $\mathrm{C} 4$ grassland habitat. The hypothesis presented here should be tested by studying thoroughly the tooth microwear of the Oligocene ruminants in order to check whether they were grazer, browser or mixed feeder (Solounias and 
Dawson-Saunders, 1988; Solounias and Moelleken, 1992) and to know whether tooth microwear differences are exhibited between a $\mathrm{C} 4$ grazer and a $\mathrm{C} 3$ grazer.

\section{Acknowledgements}

I thank S. Ducrocq (CNRS, MontpellierII), J. Sudre (E.P.H.E, MontpellierII), J. Hooker and the anonymous reviewer for critical comments.

\section{References}

Aguilar, J.-P., Legendre, S., Michaux, J., 1997. Biochronologie mammalienne du Cénozoïque en Europe et domaine reliés. Actes du Congrès BiochroM'97. Mém. Trav. E. P. H. E., Montpellier, $818 \mathrm{pp}$.

Baker, G., Jones, L.H.F., Wardrop, L.D., 1959. Cause of wear in sheep's teeth. Nature 184, 1583-1584.

Beard, K.C., 1998. East of Eden: Asian as an important center of taxonomic origination in mammalian evolution. Dawn of the Age of Mammals in Asia, Beard, K., Dawson, M. (Eds.). Bull. Carnegie Mus. nat. Hist. 34, 5-39.

Berggren, W.A., Prothero, D.R., 1992. Eocene-Oligocene climatic and biotic evolution: an overview. In: Prothero, D.R., Berggren, W.A. (Eds.), Eocene-Oligocene Climatic and Biotic Evolution. Princeton University Press, Oxford, pp. 1-28.

Blondel, C., 1996. Les ongulés à la limite Eocène/Oligocène et au cours de 1'Oligocène en Europe occidentale: analyses faunistiques, morpho-anatomiques et biogéochimiques $(\delta 13 \mathrm{C}$,

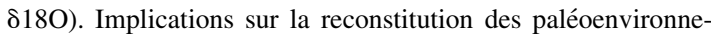
ments. Unpublished PhD, University Montpellier II.

Blondel, C., 1997. Les ruminants de Pech Desse et de Pech du Fraysse (Quercy; MP 28): évolution et relations des ruminants de l'Oligocène d'Europe. Géobios 30 (4), 573-591.

Blondel, C., Bocherens, H., Mariotti, A., 1997. Stable carbon and oxygen isotope ratios in ungulate teeth from French EoceneOligocene localities. Bull. Soc. Géol. France 168 (6), 83-89.

Blondel, C., 1998. Etude morphologique du squelette appendiculaire des ruminants de l'Oligocène d'Europe occidentale; implications environnementales. C. R. Acad. Sci. Paris 326 (7), $527-$ 532.

de Bonis, L. (Ed.), 1995a. Le Garouillas et les sites contemporains (Oligocène, MP 25) des phosphorites du Quercy (Lot, Tarn-etGaronne, France) et leurs faunes de Vertébrés. Palaeontographica Abt. A, 236 (1-6), 343 pp.

de Bonis, L., 1995b. Le Garouillas et les sites contemporains (Oligocène, MP 25) des phosphorites du Quercy (Lot, Tarn-etGaronne, France) et leurs faunes de Vertébrés. 9. Périssodactyles: Amynodontidae. Palaeontographica Abt. A 236 (1-6), 157-175.

de Bonis, L., 1995c. Le Garouillas et les sites contemporains (Oligocène, MP 25) des phosphorites du Quercy (Lot, Tarn-et-
Garonne, France) et leurs faunes de Vertébrés. 11. Chalicotherioidea. Palaeontographica Abt. A 236 (1-6), 191-204.

de Bonis, L., Brunet, M., 1995. Le Garouillas et les sites contemporains (Oligocène, MP 25) des phosphorites du Quercy (Lot, Tarn-et-Garonne, France) et leurs faunes de Vertébrés. 10. Allaceropinae et Rhinocerotidae. Palaeontographica Abt. A 236 (16), 177-190.

Bouvrain, G., Geraads, D., Sudre, J., 1986. Révision taxonomique de quelques Ruminants oligocènes des phosphorites du Quercy. C. R. Acad. Sci. Paris 302 (2), 101-104.

Brunet, M., 1977. Les Mammifères et le problème de la limite Eocène-Oligocène en Europe. Géobios Mém. Spéc. 1, 11-27.

Brunet, M., 1979. Les grands mammifères chefs de file de l'immigration Oligocène et le problème de la limite Eocène-Oligocène en Europe. Singer Polignac, Paris, 281 pp.

Brunet, M., Jéhenne, Y., 1989. Révision des genres Plagiolophus POMEL, 1847 et Paloplotherium OWEN, 1848, Mammalia, Palaeotheriidae du Paléogène d'Europe; Intérêt biochronologique. Ann. Paleontal. 75 (1), 23-52.

Brunet, M., Sudre, J., 1987. Evolution et systématique du genre Lophiomeryx POMEL, 1853 (Mammalia, Artiodactyla). Münchner Geowiss. Abh., (A) 10, 225-242.

Cavelier, C., 1979. La limite Eocène-Oligocène en Europe occidentale. Sci. Géol. Strasb., Mém. 54, 1-280.

Cerling, T.E., 1992. Development of grasslands and savannas in East Africa during the Neogene. Palaeogeogr. Palaeoclimatol. Palaeoecol. (Global Planet. Change Section) 97, 241-247.

Cerling, T.E., Ehleringer, J.R., Harris, J.M., 1998. Carbon dioxide starvation, the development of C4 ecosystems, and mammalian evolution. Philos. Trans. R. Soc. London B 353, 159-171.

Cerling, T.E., Harris, J.M., Macfadden, B.J., Leakey, M.G., Quade, J., Eisenmann, V., Ehleringer, J.R., 1997. Global vegetation change through the Miocene/Pliocene boundary. Nature 389, $153-158$.

Chateauneuf, J.-J., 1986. Evolution of the microflora and dinocystis at the Eocene-Oligocene boundary in Western Europe. In: Pomerol, C., Premoli-Silva, I. (Eds.), Terminal Eocene Events. Elsevier, Amsterdam, pp. 289-293.

Cifelli, R.L., 1981. Patterns of evolution among the Artiodactyla and Perissodactyla (Mammalian). Evolution 35 (3), 433-440.

Collinson, M.E., 1992. Vegetational and floristic changes around the Eocene/Oligocene boundary in Western and Central Europe. In: Prothero, D.R., Berggren, W.A. (Eds.). Eocene-Oligocene Climatic And Biotic Evolution, 22. Princeton University Press, Oxford, pp. 437-450.

Collinson, M.E., Fowler, K., Boulter, M.C., 1981. Floristic changes indicate a cooling climate in the Eocene of southern England. Nature 291, 315-317.

Collinson, M.E., Hooker, J.J., 1987. Vegetational and mammalian faunal changes in the Early Tertiary of southern England. In: Chaloner, W.G., Crane, P.R., Friis, E.M. (Eds.), The Origin of Angiosperms and their Biological Consequences. Cambridge University Press, Cambridge, pp. 259-304.

Collinson, M.E., Hooker, J.J., 1991. Fossil evidence of interactions between plants and plant-eating mammals. Philos. Trans. R. Soc. London B 333, 197-208.

Dedieu, P., 1976. Les Tapirö̈dea (Mammalia, Perissodactyla) du 
gisement lutétien d'Issel (Aude). Thesis, University Poitiers, $159 \mathrm{pp}$.

Ducrocq, S., 1995. The contribution of Paleogene anthracotheriid artiodactyls in the paleobiogeographical history of southern Europe. N. Jb. Geol. Paläont. Mh. H. 6, 355-362.

Ehleringer, J.R., Sage, R.F., Flanagan, L.B., Pearcy, R.W., 1991. Climate change and the evolution of $\mathrm{C} 4$ photosynthesis. Trends Ecol. Evol. 6 (3), 95-99.

Erfurt, J., 1995. Taxonomie der eozänen Artiodactyla (Mammalia) des Geiseltales mit besonderer Berücksichtigung der Gattung Rhagatherium. Hallesches Jahrb. Geowiss., B 17, 47-58.

Erfurt, J., Haubold, H., 1989. Artiodactyla aus den eozänen braunkohle des Geiseltales bei Halle. Palaeovertebrata 19 (3), 131160.

Erfurt, J., Sudre, J., 1995a. Revision der Gattung Meniscodon RÜTIMEYER 1888 (Artiodactyla, Mammalia) aus dem Mitteleozän Europas. Eclog. Geol. Helv. 88 (3), 865-883.

Erfurt, J., Sudre, J., 1995b. Un Haplobunodontidae nouveau Hallebune krumbielgeri nov. gen. nov. sp. (Artiodactyla, Mammalia) dans l'Eocène moyen du Geiseiltal près Halle (Sachsen-Anhalt, Allemagne). Palaeovertebrata 24 (1-2), 85-99.

Erfurt, J., Sudre, J., 1996. Eurodexinae, eine neue Unterfamilie der Artiodactyla (Mammalia) aus dem Unter-und Mitteleozän Europas. Palaeovertebrata 25 (2-4), 371-390.

Estravis, C., Russell, D.E., 1989. Découverte d'un nouveau Diacodexis (Artiodactyla, Mammalia) dans l'Eocène inférieur de Silveirhina, Portugal. Palaeovertebrata 19 (1), 29-44.

Fischer, K.H., 1964. Die tapiroiden Perissodactylen aus der eozänen Braunkohle des Geiseltales. Zeitschr. deutsch. geol. Ges. Berlin 13 (45), 1-101.

Franzen, J.L., 1995. Die Equoidea des europäischen Mitteleozäns (Geiseltalium). Hallesches Jahr. Geowiss., B 17, 31-45.

Galbreath, E.C., 1974. Stipid grass "seeds" from the Oligocene and Miocene deposits of northeastern Colorado. Trans. Illinois Acad. Sci. 67, 366-368.

Gingerich, P.D., 1989. New earliest Wasatchian mammalian fauna from the Eocene of northwestern Wyoming: composition and diversity in ararely sampled high-floodplain assemblage. Pap. Paleont. Mus. Paleontol., Univ. Mich., Ann Arbor, 28, pp. 1-97.

Gruas-Cavagnatto, C., 1974. Associations sporopolliniques et microplanctoniques de l'Eocène et de l'Oligocène inférieur du Bassin de Paris. Paléobiologie continentale 2, 1-20.

Haq, B.U., Hardenbol, J., Vail, P.R., 1987. Chronology of fluctuating sea levels since the Triassic. Science 235 (4793), 11561167.

Hartenberger, J.-L., 1983. La Grande Coupure. Pour la Science 67, 26-38.

Hartenberger, J.-L., 1987. Modalités des extinctions et apparitions chez les Mammifères du Paléogène d'Europe. Mém. Soc. Géol. France 150, 133-143.

Heissig, K., 1979. Die hypothetische Rolle Südosteuropas bei den Saügetierwanderungen im Eozän und Oligozän. N. Jb. Geol. Paläont. Mh. 2, 83-96.

Hellmund, M., 1991. Revision der europäischen Species der Gattung Elomeryx Marsch 1894 (Anthracotheriidae, Artiodactyla, Mammalia)-odontologische Untersuchungen. Palaeontographica Abt., A 220 (1-3), 1-101.
Hellmund, M., 1992. Schweineartige (Suina, Artiodactyla, Mammalia) aus oligo-miozänen Fundstellen Deutschlands, der Schweiz und Frankreichs II. Revision von Palaeochoerus POMEL 1847 und Propaleochoerus STEHLIN 1899 (Tayassuidae). Stuttgarter Beitr. Naturk., B 189, 1-75.

Hooker, J.J., 1989. Mammals from the Bartonien (Middle/Late Eocene) of the Hampshire Basin, Southern England. Bull. Brit. Mus. Nat. Hist. (Geol.) 39, 191-478.

Hooker, J.J., 1994. The beginning of the equoid radiation. Zoo. J. Linn. Soc. 112, 29-63.

Janis, C.M., 1976. The evolutionary strategy of the Equidae and the origins of rumen and cecal digestion. Evolution 30, 757-774.

Janis, C.M., 1988. An estimation of tooth volume and hypsodonty indices in ungulate mammals, and the correlation of these factors with dietary preference. In: Russell, D.E., Santoro, J.P., Sigogneau-Russell, D. (Eds.), Teeth Revisited: Proceedings of the VII International Symposium on dental Morphology, Paris 1986, Mém. Mus. Natn. Hist. Nat. Paris, C vol. 53, pp. 367-387.

Janis, C.M., 1989. A climatic explanation for patterns of evolutionary diversity in ungulate mammals. Palaeontology 32 (3), 463481.

Janis, C.M., 1993. Tertiary mammal evolution in the context of changing climates, vegetation, and tectonic events. Annu. Rev. Ecol. Syst. 24, 467-500.

Janis, C.M., 1995. Correlations between craniodental morphology and feeding behavior in ungulates: reciprocal illumination between living and fossil taxa. In: Thomason, J.J. (Ed.), Functional Morphology in Vertebrates Paleontology. Cambridge University Press, Cambridge, pp. 76-98.

Janis, C.M., 1998. Evolution of tertiary mammals of North America. In: Janis, C., Scott, K.M., Jacobs, L.L. (Eds.). Terrestrial Carnivores, Ungulates, And Ungulatelike Mammals, 1. Cambridge University Press, Cambridge (691 pp.).

Jéhenne, Y., 1985. Les Ruminants primitifs du Paléogène et du Néogène inférieur de l'Ancien Monde: systématique, phylogénie, biostratigraphie. Thesis, University Poitiers, 228 pp.

Jéhenne, Y., Brunet, M., 1992. Interêt biochronologique de quelques grands mammifères ongulés de l'Eocène supérieur et l'Oligocène d'Europe. Géobios Mém. spéc. 14, 201-206.

Kuypers, M.M., Pancost, R.D., Sinninghe Damste, J.S., 1999. A large and abrupt fall in atmospheric $\mathrm{CO} 2$ concentration during Cretaceous times. Nature 399, 342-345.

Langer, P., 1987. Evolutionary patterns of Perissodactyla and Artiodactyla (Mammalia) with different types of digestion. Z. zool. Syst. Evol.-forsch. 25 (3), 212-236.

Leduc, P., 1996. Caractéristiques évolutives des faunes de mammifères d'Europe occidentale et d'Amérique du Nord au Paléogène. Thesis, University Paris VI, $452 \mathrm{pp}$.

Legendre, S., 1986. Analysis of mammalian communities from the Late Eocene and Oligocene of Southern France. Palaeovertebrata $16(4), 191-212$.

Legendre, S., 1987. Concordance entre paléontologie continentale et les événements paléocéanographiques: exemple des faunes de mammifères du Paléogène du Quercy. C. R. Acad. Sci. Paris 304 (III-2), 45-50.

Legendre, S., 1989. Les communautés de mammifères du Paléogène 
(Eocène supérieur et Oligocène) d'Europe occidentale: structures, milieux et évolution. Münchner Geowiss. Abh. (A) 16, $1-110$.

Legendre, S., Crochet, J.-Y., Godinot, M., Hartenberger, J.-L., Marandat, B., Remy, J.A., Sigé, B., Sudre, J., Vianey-Liaud, M., 1991. Evolution de la diversité des faunes de mammifères d'Europe occidentale au Paléogène (MP 11 à MP30). Bull. Soc. Géol. France 162 (5), 867-874.

Legendre, S., Hartenberger, J.-L., 1992. Evolution of mammalian faunas in Europe during the Eocene and Oligocene. In: Prothero, D.R., Berggren, W.A. (Eds.). Eocene-Oligocene Climatic And Biotic Evolution. Princeton University Press, Oxford, pp. 516528.

Legendre, S., Marandat, B., Remy, J.A., Sigé, B., Sudre, J., VianeyLiaud, M., Crochet, J.-Y., Godinot, M., 1995. Coyrou 1-2, une nouvelle faune de mammifères des phosphorites du Quercy, niveau intermédiaire (MP 20-21) proche de "la Grande Coupure". Géologie de la France 1, 63-68.

Leopold, E.B., Liu, G., Clay-Poole, S., 1992. Low-biomass vegetation in the Oligocene? Eocene-Oligocene climatic and biotic evolution. In: Prothero, D.R., Berggren, W.A. (Eds.). EoceneOligocene Climatic And Biotic Evolution. Princeton University Press, Oxford, pp. 399-420.

Lopez, N., Thaler, L., 1974. Sur le plus ancien lagomorphe européen et la "Grande Coupure" de Stehlin. Palaeovertebrata 6 (3-4), 243-251.

Macfadden, B.J., 1997. Origin and evolution of the grazing guild in New World terrestrial mammals. Trends Ecol. Evol. 12, 182 186.

Macginitie, H.D., 1953. Fossil plants of the Florissant beds, Colorado. Publ. Carnegie Inst. Wash. 599, 1-198.

Mackenna, M.C., 1980. Eocene paleolatitude, climate and mammals of Ellesmere Island. Palaeogeogr. Palaeoclimat. Palaeoecol. 30, 349-362.

Mackenna, M.C., 1983a. Holarctic landmass rearrangement, cosmic events, and Cenozoic terrestrial organisms. Ann. MO Bot. Gard. 70, 459-489.

Mackenna, M.C., 1983b. Cenozoic paleogeography of North Atlantic land bridges. In: Bott, M.H.P., Saxov, S., Talwani, M., Theide, J. (Eds.). Structure And Development Of The Greenland-Scotland Ridge. NATO Conference Series IV, Marine Sciences, 8. Plenum Press, New York, pp. 351-400.

Macnaughton, S.J., Tarrants, J.L., Macnaughton, M.M., David, R.H., 1985. Silica as a defense against herbivory and a growth promotor in African grasses. Ecology 66, 528-535.

Martinez, J.-N., Sudre, J., 1995. The astragalus of Paleogene artiodactyls: comparative morphology, variability and prediction of body mass. Lethaia 28, 197-209.

Miller, K.G., 1992. Middle Eocene to Oligocene stable isotopes, climates, and deep-water history: the Terminal Eocene Event. In: Prothero, D.R., Berggren, W.A. (Eds.). Eocene-Oligocene Climatic And Biotic Evolution. Princeton University Press, Oxford, pp. 160-176.

Ollivier-Pierre, M.-F., Gruas-Cavagnatto, C., Roche, E., Schuler, M., 1987. Eléments de flore de type tropical et variations climatiques du Paléogène dans quelques bassins d'Europe nord-occidentale. Mém. Trav. E. P. H. E., Montpellier 17, 173-205.
Pagani, M., Freeman, K.H., Arthur, M.A., 1999. Late Miocene atmospheric $\mathrm{CO}_{2}$ concentrations and the expansion of $\mathrm{C} 4$ grasses. Science 285, 876-879.

Piperno, D.R., 1989. The occurrence of phytoliths in the reproductive structures of selected tropical angiosperms and their significance in tropical paleoecology, paleoethnobotany and systematics. Rev. Palaeobot. Palynol 61, 147-173.

Pomerol, C., 1967. Esquisse paléogéographique du Bassin de paris, à l'ère tertiaire et aux temps quaternaires. Rev. Géogr. phy. et Géol. dynam. IX (1), 35-85.

Pomerol, C., Premoli-Silva, I. (Eds.), 1986. Terminal Eocene Events Elsevier, Amsterdam (414 pp.).

Prothero, D.R., 1989. Stepwise extinctions and climatic decline. In: Donovan, S.K. (Ed.). Mass Extinctions, Processes and Evidence, 11. Columbia University Press, New York, pp. 217-234.

Prothero, D.R., 1994. The Eocene-Oligocene Transition: Paradise lost. Columbia University Press, New York (291 pp.).

Prothero, D.R., 1994b. The late Eocene-Oligocene extinctions. Annu. Rev. Earth Planet. Sci. 22, 145-165.

Prothero, D.R., Heaton, T.H., 1996. Faunal stability during the Early Oligocene climatic crash. Palaeogeogr. Palaeoclimat. Palaeoecol. 127, 257-283.

Prothero, D.R., Schoch, R.M. (1989). Origin and evolution of Perissodactyla: A summary and synthesis. In: Prothero, D.R., Schoch, R.M. (Eds.), The evolution of Perissodactyls. Oxford University Press, New York, pp. 504-529.

Remy, J.A., 1995. Le Garouillas et les sites contemporains (Oligocène, MP25) des Phosphorites du Quercy (Lot, Tarn et Garonne, France) et leurs faunes de vertébrés. 8. Périssodactyles: Palaeotheriidae [Perissodactyla: Palaeotheriidae]. Palaeontographica Abt., A 236 (1-6), 151-155.

Remy, J.A., Crochet, J.-Y., Sigé, B., Sudre, J., de Bonis, L., VianeyLiaud, M., Godinot, M., Hartenberger, J.-L., Lange-Badre, B., Comte, B., 1987. Biochronologie des phosphorites du Quercy: Mise à jour des listes fauniques et nouveaux gisements de mammifères fossiles. Münchner Geowiss. Abh. 10, 169-188.

Retallack, G.J., 1992. Paleosols and changes in climate and vegetation across the Eocene/Oligocene boundary. In: Prothero, D.R., Berggren, W.A. (Eds.), Eocene-Oligocene Climatic And Biotic Evolution. Princeton University Press, Oxford, pp. 382-398.

Roiron, P., 1992. Flores, végétations et climats du Néogène méditerranéen: apports de macroflores du sud de la France et du nordouest de l'Espagne. Thesis, University Montpellier II, 296 pp.

Schmidt-Kittler, N. (Ed.), 1987. European reference levels and correlation tables. Münchner Geowiss. Abh., vol. 10, pp. 13-31.

Sigé, B., Vianey-Liaud, M., 1979. Impropriété de la Grande Coupure de Stehlin comme support d'une limite Eocène-Oligocène. Newsl. Stratigr. 8 (1), 79-82.

Smith, R., Smith, T., Sudre, J., 1996. Diacodexis gigasei n. sp., le plus ancien Artiodactyle (Mammalia) belge, proche de la limite Paléocène-Eocène. Bull. Inst. Sci. nat. Belgique 66, $177-186$.

Solounias, N., Dawson-Saunders, B., 1988. Dietary adaptations and paleoecology of the Late Miocene ruminants from Pikermi and Samos in Greece. Palaeogeogr. Palaeoclimatol. Palaeoecol. 65, 149-172.

Solounias, N., Moelleken, S.M.C., 1992. Tooth microwear analysis 
of Eotragus sansaniensis (Mammalia: Ruminantia), one of the oldest known bovids. J. Vert. Paleontol. 12 (1), 113-121.

Stebbins, G.L., 1981. Coevolution of grasses and herbivores. Ann. MO Bot. Gard. 68, 75-86.

Stehlin, H.G., 1909. Remarques sur les faunules de mammifères des couches éocènes et oligocènes du Bassin de Paris. Bull. Soc. Géol. France 4 (9), 488-520.

Stucky, R.K., 1995. Problems and speculations in mammalian paleoecology and evolution: western North America during the Paleogene. Fossils of Arizona-Vol.III, Proceedings 1995, pp. 97-103.

Sturm, M., 1978. Maw contents of an Eocene horse (Propalaeotherium) out of the oil shale of Messel near Darmstadt. In: Kvacek, Z., Schaarschmidt, F. (Eds.), Advances in Angiosperm Palaeobotany. Cour. Forsch.-Inst., Senckenberg, vol. 30, pp. 2-120.

Sudre, J., 1986. Le genre Bachitherium FILHOL, 1882 (Mammalia, Artiodactyla), diversité spécifique, phylogénie, extension chronologique. C. R. Acad. Sci., Paris II 303 (8), 749-754.

Sudre, J., 1995. Le Garouillas et les sites contemporains (Oligocène, MP25) des phosphorites du Quercy (Lot, Tarn-et-Garonne, France) et leurs faunes de Vertébrés. 12. Les artiodactyles. Palaeontographica Abt., A 236 (1-6), 205-256.

Sudre, J., Blondel, C., 1996. Sur la présence de petits gélocidés (Artiodactyla) dans l'Oligocène inférieur du Quercy (France); considérations sur les genres Pseudogelocus SCHLOSSER 1902, Paragelocus SCHLOSSER 1902 et Iberomeryx GABUNIA 1964. N. Jb. Geol. Paläont. Mh. H. 3, 169-182.

Sudre, J., ERFURT, J., 1996. Les artiodactyles du gisement yprésien terminal de Prémontré (Aisne, France). Palaeovertebrata 25 (2-4), 391-414.

Sudre, J., Legendre, S., 1992. Ungulates from Paleogene of Western Europe: relationships between their evolution and environmental changes during that period. In: Janeau, G., Spitz, F., Gonzalez, G., Aulagnier, S. (Eds.), Ongulés/Ungulates 91. Toulouse, SFEPM-IRGM, pp. 15-25.

Sudre, J., Marandat, B., 1993. First discovery of an Homacodontinae (Artiodactyla, Dichobunidae) in the Middle Eocene of western Europe: Eygalayodon montenati new genus, new species. Considerations on the evolution of primitive artiodactyla. Kaupia 3, 157-164.

Sudre, J., Russell, D.E., Louis, P., Savage, P.E., 1983. Les artiodactyles de l'Eocène inférieur d'Europe. Bull. Mus. Hist. Nat., Paris, C (3-4), 281-365.

Tieszen, L.L., Senyimba, M.M., Imbamba, S.K., Troughton, J.H., 1979. The distribution of $\mathrm{C} 3$ and $\mathrm{C} 4$ grasses and carbon isotope discrimination along an altitudinal and moisture gradient in Kenya. Oecologia 37, 337-350.

Vianey-Liaud, M., 1991. Les rongeurs de l'Eocène terminal et de l'Oligocène d'Europe comme indicateurs de leur environnement. Palaeogeogr. Palaeoclimatol. Palaeoecol. 85, 15-28.

Vianey-Liaud, M., Legendre, S., 1986. Les faunes des phosphorites du Quercy: principes méthodologiques en paléontologie des mammifères; homogénéité chronologique des gisements de mammifères fossiles. Eclog. Geol. Helv. 79 (3), 917-944.

Wang, Y., Cerling, T.E., Macfadden, B.J., 1994. Fossil horses and carbon isotopes: new evidence for Cenozoïc dietary, habitat, and ecosystem changes in North America. Palaeogeogr. Palaeoclimatol. Palaeoecol. 107, 269-279.

Wing, S.L., 1998. Tertiary vegetation of North America as a context for mammalian evolution. In: Janis, C., Scott, K.M., Jacobs, L.L. (Eds.). Evolution of Tertiary Mammals of North America. Terrestrial Carnivores, Ungulates, and Ungulatelike Mammals, vol. 1. Cambridge University Press, Cambridge, pp. 37-60.

Wolfe, J.A., 1978. A paleobotanical interpretation of tertiary climates in the Northern Hemisphere. Am. Sci. 66, 694-703.

Wolfe, J.A., 1985. Distribution of major vegetational types during the Tertiary. In: Sundquist, E.T., Broecker, W.S. (Eds.), The carbon cycle and atmospheric $\mathrm{CO}_{2}$ : natural variations, Archean to Present. Geophysical Monogr. 32, 357-376.

Zachos, J.C., Lohmann, K.C., Walker, J.C.G., Sherwood, W.W., 1993. Abrupt climate change and transient climates during the Paleogene: a marine perspective. J. Geol. 101, 191-213.

Zachos, J.C., Stott, L.D., Lohmann, K.C., 1994. Evolution of early Cenozoic marine temperatures. Paleoceanography 9 (2), 353387. 